\title{
Direct seeding of Brazilian savanna trees: effects of plant cover and fertilization on seedling establishment and growth
}

\author{
Raíssa R. P. Silva1 ${ }^{1}$, Daniel R. Oliveira ${ }^{2}$, Gustavo P. E. da Rocha ${ }^{3}$, Daniel L. M. Vieira ${ }^{3,4}$
}

Direct seeding is a promising technique for ecological restoration, but it has been poorly studied in neotropical savannas. Different types of plant cover (no cover, crops, or green manure) and fertilization (unfertilized, synthetic fertilizer, or poultry litter) were used to verify if survival and growth of different tree species after direct seeding could be enhanced by the use of any combination of these techniques. Seedling emergence, establishment, and growth were followed for 2 years for six savanna tree species sown in an agricultural field in Central Brazil. Germination was high (52\%, on average) for Anacardium occidentale, Aspidosperma macrocarpon, Hymenaea stigonocarpa, Dipteryx alata, Eugenia dysenterica, and Magonia pubescens. Six additional species were planted, but less than $5 \%$ of these seeds germinated. Crops (60\% shade) did not affect seedling survival and biomass compared with the control treatment, supporting the use of this strategy during the initial phase of restoration to involve farmers in the process. In contrast, the excessive shading (95\%) from the green manure treatment decreased the survival of two species and the growth in biomass and diameter of five species, especially when combined with fertilization. Seedling growth was very slow throughout the experiment, requiring extended weed management. This study supports the use of direct seeding of the studied species for savanna restoration, but methods could be improved to include a larger number of species.

Key words: agroforestry, cerrado, germination, neotropical savanna, nurse plants

\section{Implications for Practice}

- Direct seeding of specific cerrado tree species is recommended for Brazilian savanna restoration, as their seedling emergence and survival rates are high. However, seeding techniques need to be improved to expand the number of species that can be planted successfully.

- Annual crops can be used to provide up to $60 \%$ shade during the initial phases of savanna tree seedling establishment, as a way to increase farmers' involvement and income.

- Fertilization favors the growth of weeds and cover plants in detriment of tree seedlings.

- The slow growth of savanna tree seedlings requires extensive weed control. Planting native grasses, herbs, and shrubs to cover the ground may be a useful strategy to prevent invasion by exotic species.

\section{Introduction}

The Brazilian cerrado is a tropical savanna typically dominated by grasses with scattered trees and shrubs. Thirty-seven percent of the cerrado biome has been converted for agriculture and pasture (Sano et al. 2008). In fact, this biome has the largest rate of land-use conversion to mechanized agriculture in Brazil

(Lapola et al. 2014), but methodologies for cerrado restoration are virtually absent.

Savannas have unique natural regeneration traits that should be taken into consideration when developing restoration methods. For instance, tree seedling recruitment is constrained by seed limitation and seedling establishment (Salazar et al. 2012b; Clark et al. 2013). Tree seed limitation in cerrado may be caused by (1) low investment in sexual reproduction, compensated by high investment in vegetative reproduction and survival through resprouting (Hoffmann 1998); (2) low tree density resulting in low seed rain (Salazar et al. 2012b); (3) the absence of a persistent soil seed bank (Salazar et al. 2011); and (4) reduced availability of seeds caused by fire (Hoffmann \& Solbrig 2003). Tree

Author contributions: DLMV, DRO conceived the research; RRPS, DRO, GPER performed the experiments; RRPS analyzed the data; RRPS, DLMV lead manuscript writing.

${ }^{1}$ Universidade de Brasília, Pós Graduação em Ciências Florestais, Asa Norte, 70910-900 Brasília, DF, Brazil

${ }^{2}$ EMATER-DF, SAIN, Parque Estação Biológica, Ed. Sede, 70770-915 Brasília, DF, Brazil

${ }^{3}$ Laboratório de Ecologia e Conservação, Embrapa Recursos Genéticos e Biotecnologia, Asa Norte, Caixa Postal 02372, 70770-900 Brasília, DF, Brazil

${ }^{4}$ Address correspondence to D. L. M. Vieira, email daniel.vieira@embrapa.br

(C) 2015 Society for Ecological Restoration

doi: $10.1111 /$ rec. 12213

Supporting information at:

http://onlinelibrary.wiley.com/doi/10.1111/rec.12213/suppinfo 
seedling establishment is limited by competition with grasses and by fluctuations in precipitation and fire intensity (Higgins et al. 2000). In the absence of fire, the survival of tree seedlings is high (Moreira 2000), and may reach $80 \%$ for 16 tree species in 1 year (Salazar et al. 2012a). Seedling survival in the first 8 months is greater under tree crowns (40-60\% shade) than under intermediate shade (10-40\%) and in open areas (Salazar et al. 2012a). In addition, although Brazilian savanna trees are adapted to low fertility soils, tree seedlings can respond positively to the addition of nutrients by favoring shoot growth (Sassaki \& Felippe 1998; Hoffmann \& Franco 2003; but see Viani et al. 2011 for different results). In general, seedling establishment of Brazilian savanna tree species is favored by the absence of fire, up to $60 \%$ shade, low grass biomass, and increased nutrient availability in the upper soil layers (Salazar et al. 2012b).

Given that seedling establishment is naturally high, direct seeding of tree species can potentially be used for cerrado restoration, once the bottleneck of seed limitation is solved. This requires the initial exclusion of fire and the amelioration of microclimatic extremes. In recent years, direct seeding of native trees has been used as a low-cost alternative for restoration (Engel \& Parrotta 2001; Wallin et al. 2009). The advantages of this technique are the reduction of up to $40 \%$ of the costs, by cutting down labor and avoiding nurseries (Engel \& Parrotta 2001; Cole et al. 2011), and the high density of seeds planted, generating seedling densities similar to those found in natural clearings (Muehlethaler \& Kamm 2009; Campos-Filho et al. 2014). However, there are some issues with direct seeding. For instance, competition with weeds is prolonged because seedlings remain in the herbaceous layer longer than nursery-grown seedlings (Riginos 2009), and there is increased seed predation, and seed and seedling mortality by desiccation due to high temperatures in open areas (Engel \& Parrotta 2001; Doust et al. 2006, 2008).

Sowing agricultural crops or fast-growing green manure as cover plants may shade tree seedlings during their early life stages, improve physical and chemical soil properties, and mitigate microclimate extremes, which ultimately may improve the establishment of tree seedlings (Balandier et al. 2009; Vieira et al. 2009). Combining agricultural species and methodologies with direct seeding also allows for cost reduction through crop harvesting, and may help getting landowners involved in the restoration activities because these methods resemble their daily agricultural practices (Vieira et al. 2009; Durigan et al. 2013). However, it is necessary to improve our understanding of the impacts of agricultural species on tree seedling establishment. This study aimed to evaluate the emergence, establishment, and growth of six cerrado tree species directly sown in an area of mechanized agriculture set aside for restoration. The effects of plant cover (no cover, crops, or green manure), fertilization (unfertilized, synthetic fertilizer, or poultry litter), and their interactions were tested. We expected that (1) plant cover (crops and green manure) would increase seedling survival in the first year after emergence, but would reduce growth of the surviving seedlings by reducing light availability; in this study, green manure species were planted at high densities, providing more shade than crops, thus we were able to test two densities of plant cover; (2) fertilization would promote seedling growth, as observed previously for some of the studied species (Sassaki \& Felippe 1998; de Souza et al. 2001; Lacerda et al. 2011); poultry litter is expected to have a larger effect than NPK (nitrogen, phosphorus, and potassium) because it releases nutrients more gradually, allowing the slow-growing savanna trees to utilize nutrients for a longer period; (3) the interaction of plant cover with fertilization would favor the growth of crops and green manure to the point of decreasing tree seedling growth.

\section{Methods}

\section{Study Area}

The study was conducted in Fazenda Sucupira, an experimental farm owned by Embrapa (Brazilian Corporation of Agricultural Research), located $21 \mathrm{~km}$ southwest of Brasilia, Brazil $\left(15^{\circ} 54^{\prime} 09^{\prime \prime} \mathrm{S}\right.$ and $\left.48^{\circ} 01^{\prime} 53^{\prime \prime} \mathrm{W}\right)$, at an elevation of $1,200 \mathrm{~m}$. The mean annual rainfall is $1,578 \mathrm{~mm}(\mathrm{SD}=168 \mathrm{~mm})$, and $84 \%$ of the precipitation falls from October to March. The mean annual temperature is $21^{\circ} \mathrm{C}$, with average maximum of $22^{\circ} \mathrm{C}$ in September and average minimum of $18^{\circ} \mathrm{C}$ in July (INMET 2014). The soil is a dark-red latosol (oxisol), and a soil analysis of the experimental site indicates that it is more fertile than typical cerrado soils (data not shown). The farm has 1,763 ha, and the study plots covered approximately 9 ha. For 32 years, there has been mechanized no-tillage cultivation of grains of the experimental site. The old-growth area adjacent to the experimental site is a cerrado with 1,822 trees/ha $(>5 \mathrm{~cm}$ diameter at $30 \mathrm{~cm}$ height) and a basal area of $8.7 \mathrm{~m}^{2} / \mathrm{ha}$. The most abundant tree species are Ouratea hexasperma, Kielmeyera coriacea, Eremanthus glomerulatus, Vochysia thyrsoidea, Erythroxylum suberosum, Vellozia squamata, Qualea parviflora, Rapanea guianensis, Sclerolobium paniculatum, and Dalbergia miscolobium (Walter \& Sampaio 1998).

\section{Tree Species}

Our experiment initially included 12 savanna tree species that are widespread and abundant in the Cerrado biome (Table 1). All species are heliophytic, commonly becoming exposed to full sun after growing taller than the grass layer of $50 \mathrm{~cm}$. However, the mean emergence of Eriotheca pubescens, Terminalia argentea, and Tabebuia aurea was below 10\%, Caryocar brasiliense had dormant seeds and did not emerge during the first year of experiment, and Acrocomia aculeata and Annona crassiflora did not emerge at all during this study. These species were excluded from the analyses because it would not be possible to detect treatment effects. A total of six tree species were evaluated.

The fruits and seeds of the 12 species were collected in cerrado remnants within a $50 \mathrm{~km}$ radius of the experimental area. At least five mother trees per species were selected for collection. Seeds were removed from fruits and stored untreated in paper bags at room temperature for up to 4 months before they were sown. The exception was Eugenia dysenterica seeds, which are recalcitrant and were stored in vermiculite. We did not treat seeds to break dormancy before seeding, and the viability of the seeds was not assessed by germination trials in the laboratory. 
Table 1. Mean (min-max) seed mass, water content, and percent seedling emergence of cerrado tree species used in the direct seeding experiments across nine treatments.

\begin{tabular}{|c|c|c|c|}
\hline Species & Seed Mass $(g)^{\mathrm{a}}$ & Water Content $(\%)^{\mathrm{a}}$ & Emergence in the Field Experiments $(\%)^{\mathrm{b}}$ \\
\hline Annona crassiflora Mart. & 0.68 & 33 & - \\
\hline Acrocomia aculeata (Jacq.) Lodd. ex Mart. & 12.2 & 35 & - \\
\hline Tabebuia aurea (Silva Manso) Benth. \& Hook.f. ex S.Moore & 0.23 & 14 & $4.1(0.8-7.5)$ \\
\hline Caryocar brasiliense Cambess. & 4.85 & 21 & $12.4(7.5-20.0)$ \\
\hline Dipteryx alata Vogel & 1.20 & 6 & $19.0(13.3-24.2)$ \\
\hline Eriotheca pubescens (Mart. \& Zucc.) Schott \& Endl. & 0.23 & 11 & $4.3(0.8-7.5)$ \\
\hline Eugenia dysenterica (Mart.) DC. & 0.75 & 43 & $74.0(67.5-82.5)$ \\
\hline Magonia pubescens A.St.-Hil. & 2.10 & 6 & $53.5(40.0-65.8)$ \\
\hline
\end{tabular}

${ }^{\text {a}}$ Salomão et al. (2003) for all species except A. occidentale and A. aculeata (D. A. Silva, personal communication).

${ }^{\mathrm{b}}$ Results of this study.

\section{Experimental Design}

The experiment was conducted using a factorial block design, crossing the factors fertilization (unfertilized, synthetic fertilizer-NPK, or poultry litter-PL) and plant cover (no cover, crops, or green manure-GM) for a total of nine treatment combinations. We established four blocks, $100 \mathrm{~m}$ apart each (Fig. S1, Supporting Information). Each block contained nine 30-m-long parallel rows $5 \mathrm{~m}$ from each other, and each row received a different treatment combination. In each row, we sowed one seed of each species per meter, for a total of 12 species (and seeds) per meter and 30 seeds of each species per treatment combination (row) per block (30 seeds $\times 9$ treatments $\times 4$ blocks $=1,080$ seeds of each species). No seeds of Aspidosperma macrocarpon were planted in block 4 due to a shortage of seeds, and the control/control treatment for Magonia pubescens was not planted in block 1 by mistake.

Fertilization Treatments. For the synthetic fertilizer treatment, $253 \mathrm{~g}$ of NPK $(4: 14: 8)$ and $84 \mathrm{~g}$ of natural phosphate were applied per linear meter. For the poultry litter fertilization, $1,500 \mathrm{~g}$ of fertilizer plus $44 \mathrm{~g}$ of natural phosphate were spread per linear meter, in three rows per block. The amount of fertilizer used was based on the recommendations for fertilization of nursery-grown seedlings, treating each linear meter as a $25 \mathrm{~cm}$ diameter $\times 100$-cm-long cylinder.
Plant Cover Treatments. For the crop cover treatment, three maize seeds (Zea mays L.) were sown every $60 \mathrm{~cm}$, interspersed with two cassava cuttings (Manihot esculenta Crantz) every $120 \mathrm{~cm}$. For the green manure cover treatment, castor bean (Ricinus communis L.) was sown every $120 \mathrm{~cm}$, and jack bean (Canavalia ensiformis L.) every $30 \mathrm{~cm}$ (Table 2, Fig. 1). We assessed light interception and soil moisture to characterize the environment under different treatments. The level of light reaching tree seedlings $10 \mathrm{~cm}$ tall was estimated from the ratio between the photosynthetic photon flux density (PPFD) under the cover treatments and the PPFD in full sun on a cloudless day between 10:00 and 14:00; PPFDs were measured with a LI-190 point quantum sensor (LI-COR, Lincoln, NE, U.S.A.). Measurements were taken 5 months after planting, when crops and green manure had reached their maximum biomass (Table 2). Five measurements were taken for each row. Soil moisture was obtained gravimetrically by collecting two soil samples per row (eight samples per treatment) 8 months after planting, at the beginning of the dry season (Table 2).

The experiment was established in November 2010, at the beginning of the rainy season. In each row, the soil was plowed in a 1-m-wide strip and furrowed to a depth of $40 \mathrm{~cm}$ at the center of the strip using a ridger. After fertilization, the furrows were refilled with soil, covering the fertilizer and leveling the ground, and the cassava cuttings and all the seeds were planted. Straw grass (mulch) was spread within $50 \mathrm{~cm}$ of each side of

Table 2. Characteristics of crops and green manure used as cover plants for direct seeding of cerrado trees, in Brasília, DF.

\begin{tabular}{|c|c|c|c|c|}
\hline Characteristics & \multicolumn{2}{|c|}{ Crops } & \multicolumn{2}{|c|}{ Green Manure } \\
\hline Spacing $(\mathrm{cm})$ & 60 & 120 & 120 & 30 \\
\hline Height & $180 \mathrm{~cm}$ & $220 \mathrm{~cm}$ & $250 \mathrm{~cm}$ & $50 \mathrm{~cm}$ \\
\hline Light interception ${ }^{\mathrm{a}}$ & & & & \\
\hline Soil Moisture ${ }^{\mathrm{a}}$ & & & & \\
\hline
\end{tabular}

${ }^{\mathrm{a}}$ Mean values observed in this study. 

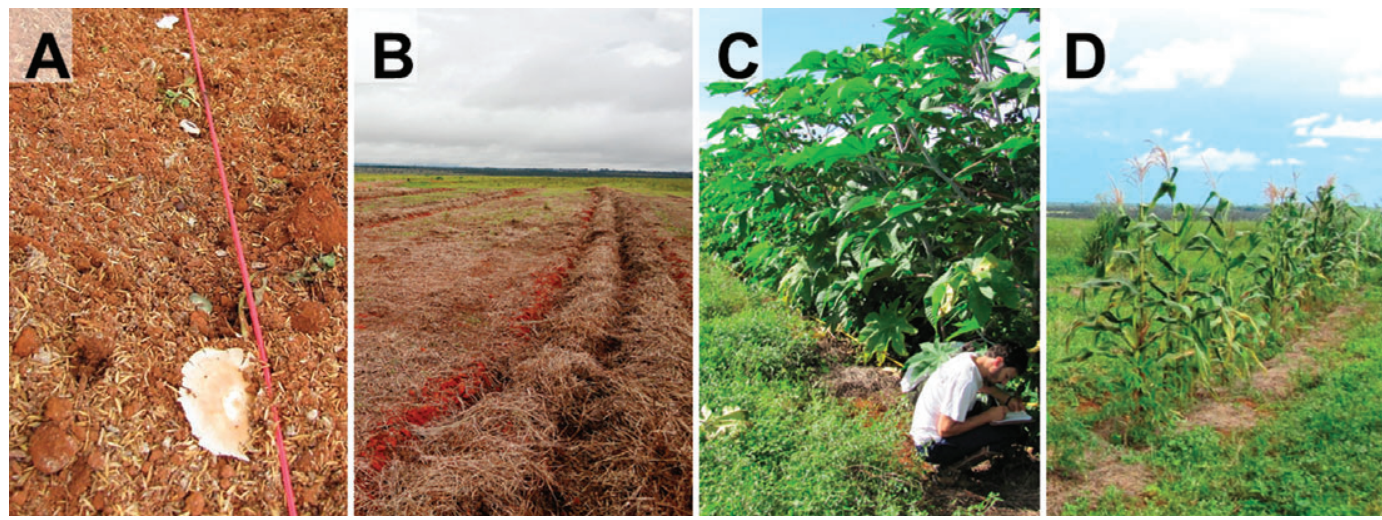

Figure 1. Direct seeding of cerrado trees intercropped with cover plants in Brasília, Central Brazil. (A) Seeds were sown along a 30-m-long row, with one seed of each species per meter, totalling 12 seeds $/ \mathrm{m}$. (B) Straw grass (mulch) spread on the rows. Note the hollow in the middle of the mulch, where seeds were sown. (C) Treatment with green manure 4 months after sowing. Castor beans were spaced $120 \mathrm{~cm}$ apart and jack beans $30 \mathrm{~cm}$ apart. (D) Treatment with crops 4 months after sowing. Maize was spaced $60 \mathrm{~cm}$ apart and cassava $120 \mathrm{~cm}$ apart.

the sowing line to reduce weed emergence and maintain soil moisture. Mechanical mowing between rows and hand weeding of the rows occurred at the end of each rainy season.

\section{Measurements and Data Analyses}

Seedling emergence and survival were evaluated $42,84,126$, 217,398 , and 780 days after planting. Keeping track of seedling emergence and survival was straightforward because, within a row, there was one seed of each species every meter. To determine growth, we measured aboveground and belowground seedling biomass for the five species with the highest emergence ratios (Anacardium occidentale, A. macrocarpon, E. dysenterica, Hymenaea stigonocarpa, and M. pubescens) after 135 days of seeding (i.e. after the first rainy season). One seedling per treatment was harvested from three blocks (for total of 27 seedlings per species). Stem height and diameter were measured at 398 days for three seedlings per species per row, and at 780 days for all seedlings.

To determine the effects of fertilization, plant cover and their interaction on emergence, establishment, and growth, factorial ANOVAs were performed for each species, treating blocks as a random variable without interaction. Height and diameter were log-transformed to approximate normal distribution. The percentages of emergence, survival, and establishment did not require transformation. We used survival analyses to compare the effects of the nine treatments on seedling survival of each species up to a year (398 days), the period of the experiment during which cover plants were present. Survival curves describe the proportion of survivors in an interval as a fraction of the number alive at the beginning of the interval. A grouped score is assigned to each survival time using Mantel's procedure, and a Chi-square value is computed for each group. To obtain a cohort of seedlings starting at the first census, we treated the emergence date of seedlings that germinated at 126 and 84 days as 42 days. Seedlings that germinated after 126 days were excluded because they spent most of the time as seeds, not seedlings, and the effects of treatment should be observed in seedlings. Using all seedlings that had germinated before 126 days allowed us to include all but $9 \%$ of the seedlings that germinated within 398 days. Seedling establishment was defined as the number of surviving seedlings at 780 days divided by the number of seeds sown. For the survival analyses, harvested seedlings were treated as censored data after 126 days, and for the establishment analyses the number of harvested seedlings was multiplied by the accumulated proportion of survival after 126 days.

\section{Results}

Combining the six tree species analyzed, 6,180 seeds were sown and 3,200 of these (52\%) germinated. It should be noted that emergence followed by mortality could have occurred between censuses dates, causing an underestimation of seedling emergence and an overestimation of survival. Fertilizer type only affected seedling emergence in Aspidosperma macrocarpon, which had lower emergence with poultry litter, especially in treatments without cover plants (no cover, unfertilized $66.7 \pm 5.1 \%$ SE; crops, unfertilized $50.0 \pm 1.9 \%$; GM, unfertilized $55.6 \pm 12.8 \%$; no cover, NPK $50.0 \pm 6.9 \%$; crops, NPK $58.9 \pm 6.8 \%$; GM, NPK $62.2 \pm 9.5 \%$; no cover, PL $12.2 \pm 4.8 \%$; crops, PL $44.4 \pm 15.7 \%$; GM, PL $34.4 \pm 8.9 \%$; Table S1)

Poultry litter and green manure increased mortality of Anacardium occidentale, A. macrocarpon, and Dipteryx alata after the first rainy season (Fig. 2). None of the treatments modified the survival of the other three species. In total, 2,333 seedlings survived to 398 days, and 2,144 seedlings survived to 780 days. This corresponded to overall establishment percentages of 38 and 34\% (based on number of seeds sown) and survival rates of 74 and 67\% (based on number of emerged seedlings) at 398 and 780 days, respectively. Seedling establishment after 780 days was lower for A. macrocarpon with poultry litter and for Magonia pubescens with green manure. Anacardium occidentale was negatively affected by both treatments (Fig. 3).

After 2 years, $D$. alata was on average $29 \mathrm{~cm}$ tall $\times 6.6 \mathrm{~mm}$ in diameter; A. occidentale was $18 \mathrm{~cm} \times 6.0 \mathrm{~mm}$; A. macrocarpon was $11 \mathrm{~cm} \times 4.7 \mathrm{~mm}$; Hymenaea stigonocarpa was 


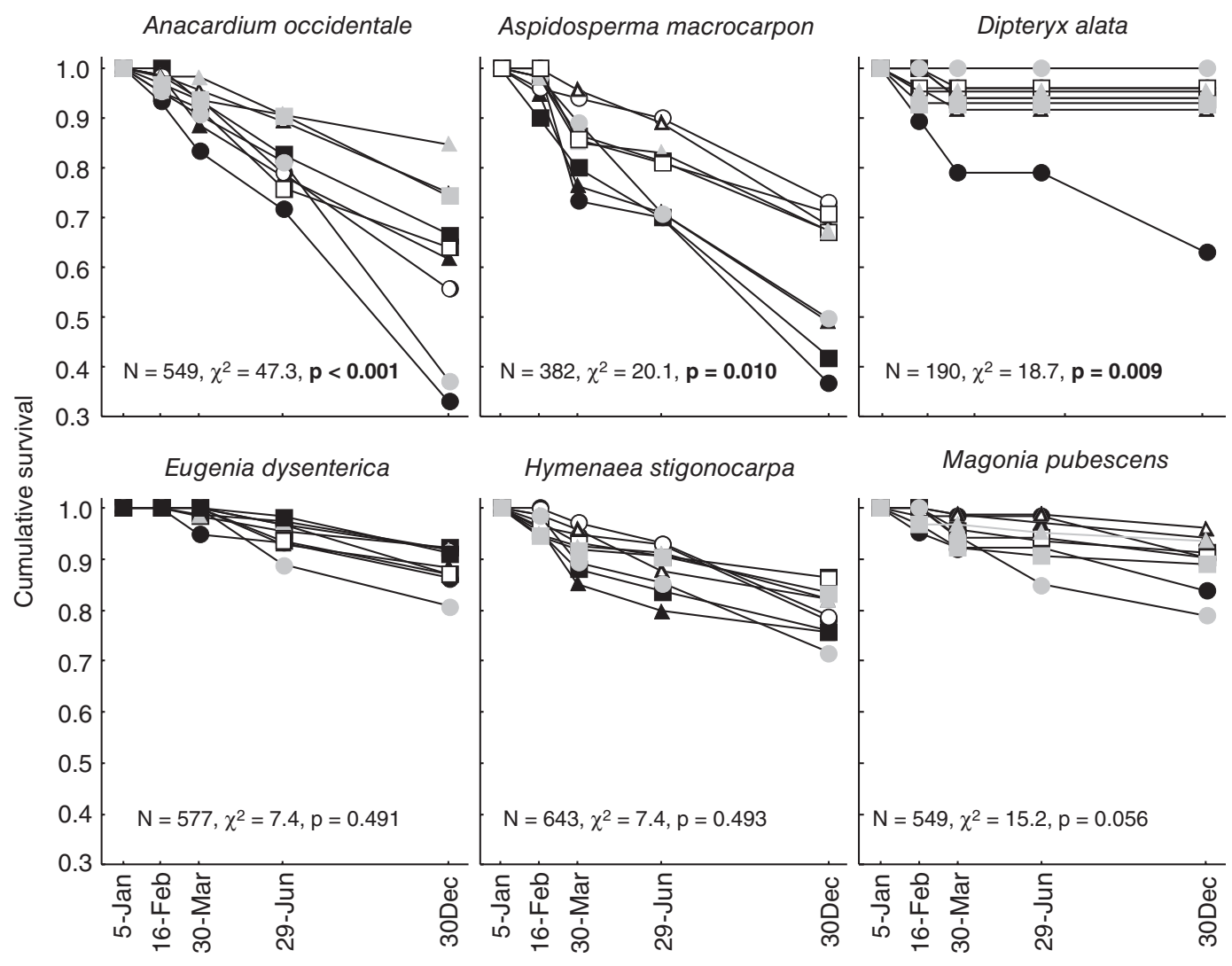

Figure 2. Cumulative seedling survival up to 398 days after seeds were sown in rows with different levels of fertilization (white, unfertilized; gray, NPK; black, poultry litter) and plant cover (squares, no cover; triangles, crops; circles, green manure). Period starts at the first census ( 42 days). Differences among survival curves were tested using Chi-square tests, and the results are shown in each plot. See Methods for details on the survival analyses.

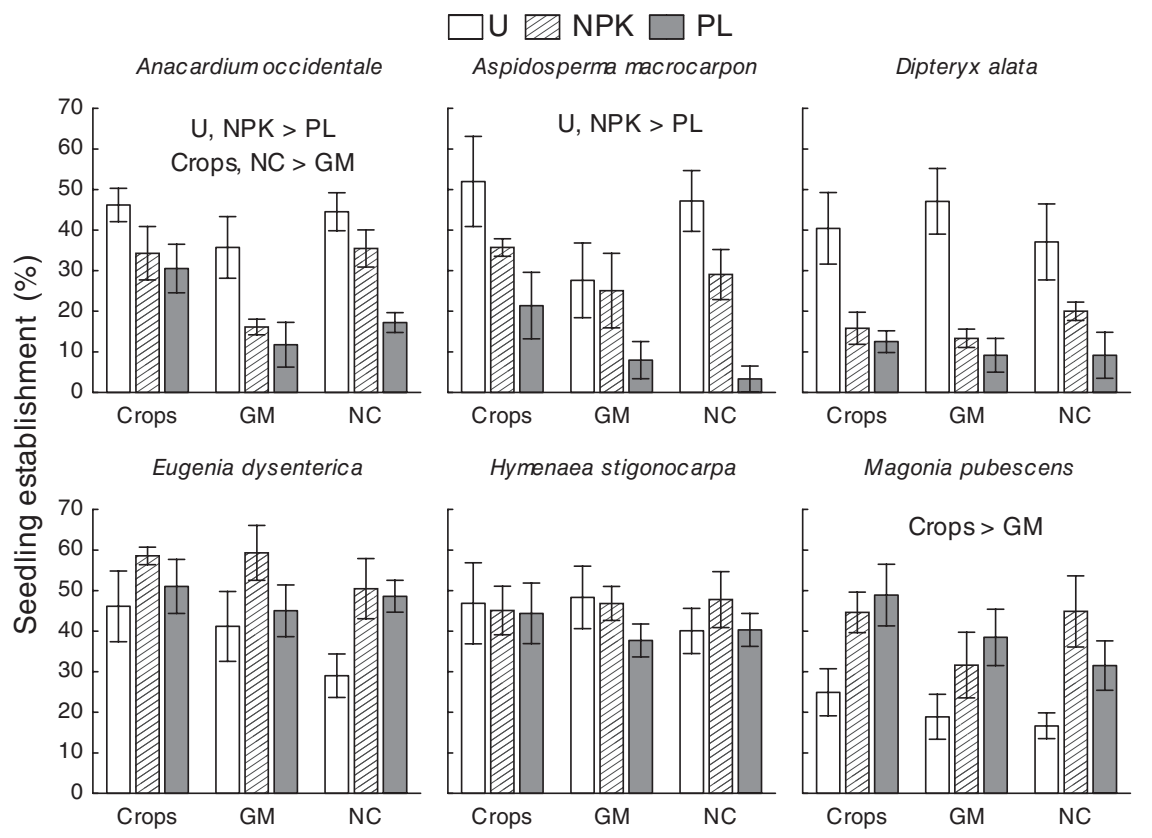

Figure 3. Seedling establishment (percentage of seedlings surviving to 780 days after seeding) of six cerrado tree species. Treatments included different levels of fertilization (U, unfertilized; NPK; or PL, poultry litter) and plant cover (NC, no cover; crops; or GM, green manure). Error bars represent \pm standard error. For each species, significant differences are shown at the top of the graph, using a greater than symbol to indicate the relatively best treatments based on factorial ANOVAs followed by Tukey tests (Table S1). 


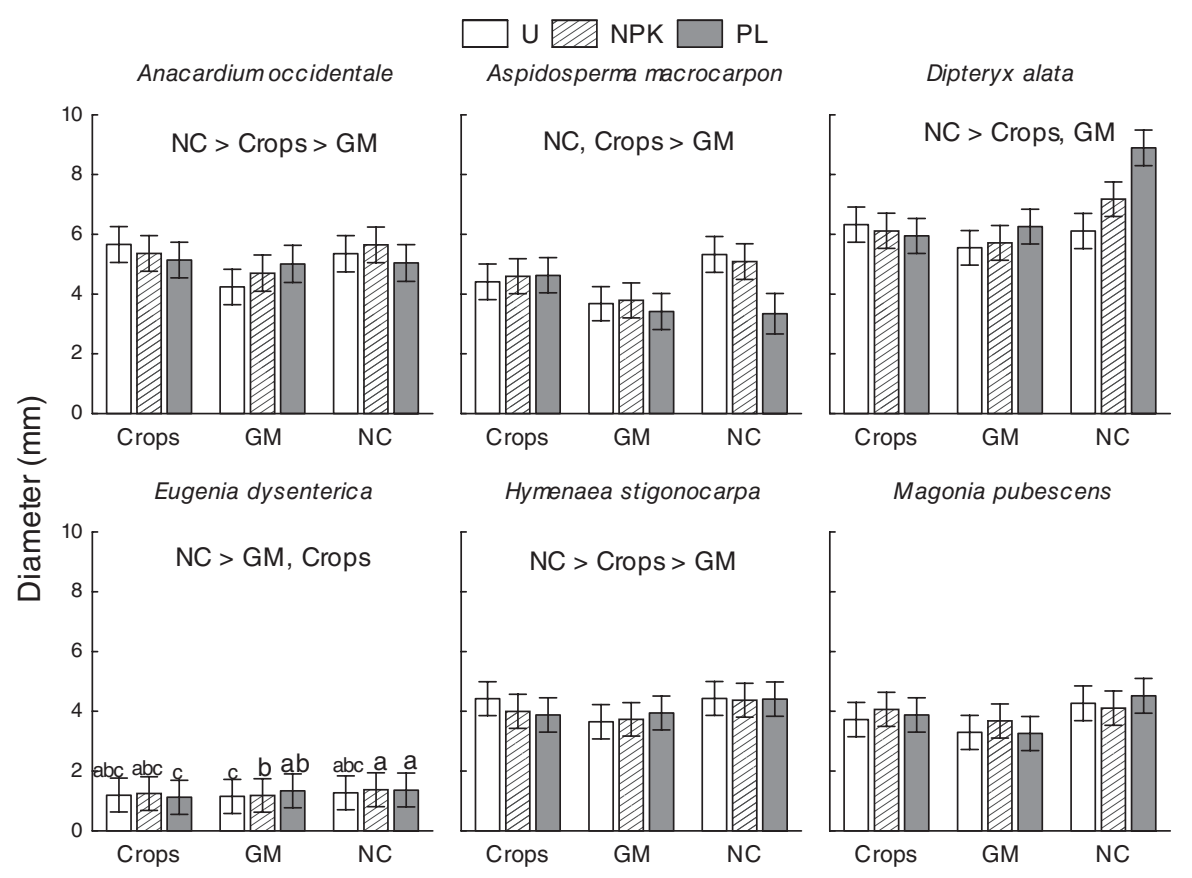

Figure 4. Seedling diameters of six cerrado tree species 780 days after seeds were sown in rows with different levels of fertilization (U, unfertilized; NPK; or PL, poultry litter) and plant cover (NC, no cover; crops; or GM, green manure]. Error bars represent \pm standard error. For each species, significant differences are shown at the top of the graph, using a greater than symbol to indicate the relatively best treatments; different letters above bars, if present, indicate significant differences among treatment interactions based on factorial ANOVAs followed by Tukey tests (Table S2). Values presented were back-transformed from $\log$.

$24 \mathrm{~cm} \times 4.3 \mathrm{~mm} ;$ M. pubescens was $19 \mathrm{~cm} \times 4.1 \mathrm{~mm}$; and Eugenia dysenterica was $9 \mathrm{~cm} \times 1.3 \mathrm{~mm}$ (for 1 year results, see Fig. S2). We will focus on diameter as a measure of growth because increased height under low light conditions may result from etiolation, which seemed to be the case for $E$. dysenterica in the presence of green manure (Fig. S3). The presence of green manure (95\% shade) limited the growth in diameter of five species, compared with seedlings without plant cover, up to 2 years after planting (Fig. 4). The growth of seedlings covered by crops was also slower compared with that of seedlings with no cover for four species, but the magnitude of the differences was only $7-13 \%$ (Fig. 4). In the second year, there was a significant interaction between treatments for E. dysenterica, and fertilized seedlings with no cover had the highest growth rate (Fig. 4).

Total seedling biomass at 135 days was on average $3.5 \mathrm{~g}$ for M. pubescens, $3 \mathrm{~g}$ for $H$. stigonocarpa, $1.6 \mathrm{~g}$ for $A$. macrocarpon, $1.3 \mathrm{~g}$ for A. occidentale, and $0.3 \mathrm{~g}$ for E. dysenterica. All species except $A$. macrocarpon had lower biomass under the green manure treatment compared with seedlings with no plant cover. Seedlings in the crop cover treatment had intermediate biomass and did not differ significantly from the control for any species (Fig. 5).

\section{Discussion}

Mean seedling emergence of Anacardium occidentale, Aspidosperma macrocarpon, Dipteryx alata, Eugenia dysenterica, Hymenaea stigonocarpa, and Magonia pubescens was relatively high (52\% across species and treatments), as well as their survival rates. However, the emergence rates of Eriotheca pubescens, Terminalia argentea, and Tabebuia aurea were below $10 \%$, Caryocar brasiliense germinated only in the second year, and Acrocomia aculeata and Annona crassiflora did not germinated during the study period. No germinability tests were carried out, so it is not possible to conclude that the species with low germination rates have low potential for direct seeding. Testing for germinability is critical to distinguish unsuccessful direct seeding from low-quality seeds. The following discussion will address the six species that were successful in converting seeds into established seedlings.

Seedling emergence was not affected by plant cover because the simultaneous seeding of cover plants and trees did not allow cover plants to develop coverage in time to affect tree seedling emergence. Cover plants may affect germination of the target species if they are sown a few months or years earlier. In addition, the straw mulch used in all treatments reduced temperature extremes and increased water retention in the soil (Truax \& Gagnon 1993; Dostalek et al. 2007), probably improving conditions for seedling establishment in all treatments. Three months after seeding, seedling survival was not significantly different under crops (60\% shade) or without plant cover. However, the excessive shading $(95 \%)$ under the green manure treatment decreased the survival of $A$. occidentale and D. alata, especially when associated with poultry litter. Most cover plants completed their life cycle in the second year, exposing seedlings to full sun. Cover plants have clear facilitative effects in lower rainfall environments such as open savannas with $450-750 \mathrm{~mm}$ 

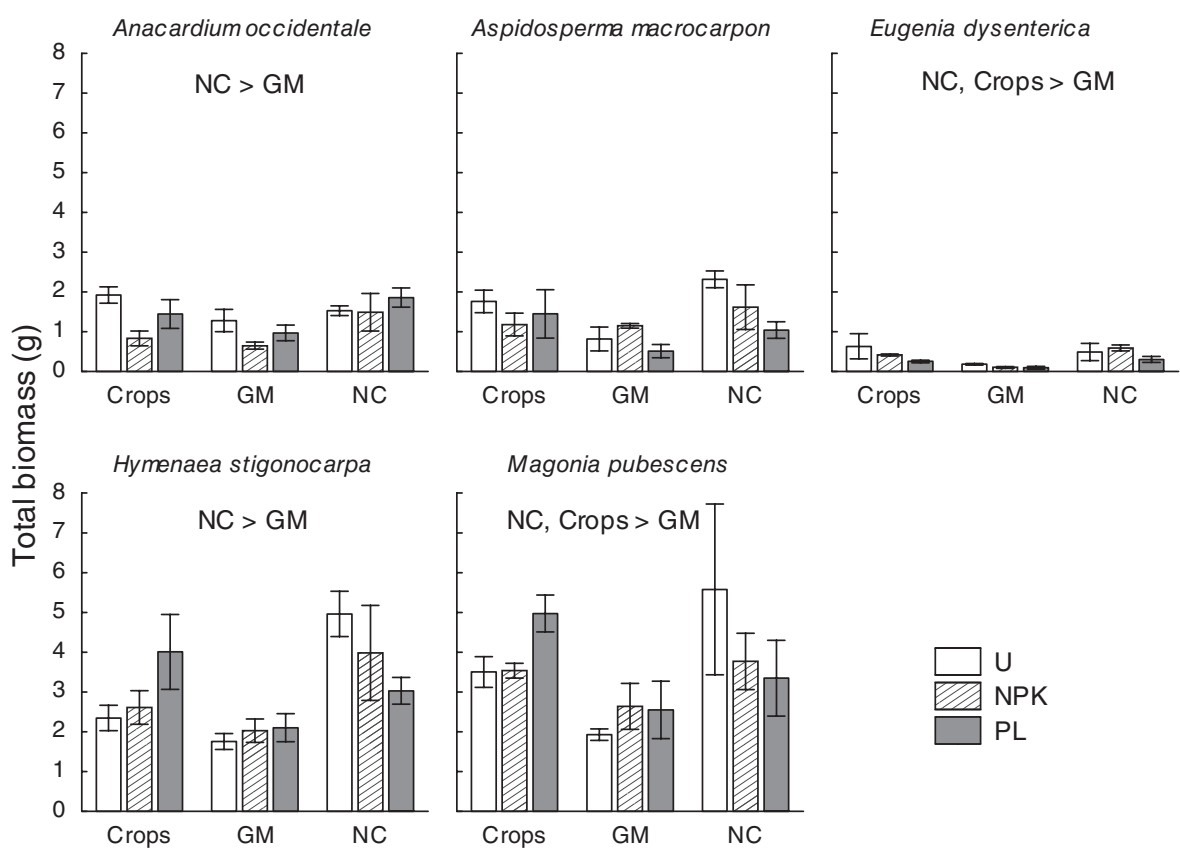

Figure 5. Total biomass of five cerrado tree seedlings harvested 135 days after seeds were sown in rows with different levels of fertilization (U, unfertilized; NPK; or PL, poultry litter) and plant cover (NC, no cover; crops; or GM, green manure). Error bars show \pm standard error. For each species, significant differences are shown at the top of the graph, using a greater than symbol to indicate the relatively best treatments, based on factorial ANOVAs followed by Tukey tests (Table S1).

of annual precipitation, where shading reduces temperature and evapotranspiration rates and improves on-site water availability (Belsky et al. 1993). However, cover plants shift from facilitators to competitors in less stressful environments (Holmgren et al. 1997; Gómez-Aparicio et al. 2004). In the cerrados of Central Brazil, 40-60\% shade increases seedling survival compared with full sun (Salazar et al. 2012a). The savanna area we studied has relatively high rainfall $(1,370 \mathrm{~mm}$ of precipitation in 2011) and mild temperatures, and the soil was fertile and unpacked by the non-tillage agriculture practiced before the experiments, allowing the plants to grow well in the first rainy season, which could reduce the need for nurse plants during the following dry season (Padilla \& Pugnaire 2006).

The low light availability in the green manure treatment, resulting from large biomass per plant and dense spacing, hindered the growth of the native seedlings studied. However, the association with crops did not reduce seedling biomass significantly, and the seedling diameter was only slightly smaller compared with that of seedlings with no plant cover. Similar results were obtained from greenhouse experiments with cerrado tree species, with higher biomass accumulation in full sun or approximately $50 \%$ shade and lower accumulation under $90 \%$ shade (Barbosa et al. 1999; Felfili et al. 1999).

Contrary to our expectations, the methods of fertilization tested did not improve seedling growth. The soil of the studied area is more fertile than that of typical cerrado soils because this area was previously used for mechanized crop cultivation, and the addition of nutrients may not have improved seedling growth. Some studies have found that cerrado species are adapted to low-fertility soils and do not respond to fertilization, and may even show reduced growth in fertilized soils (Silva \& Corrêa 2008; Martinotto et al. 2012). In this study, fertilization favored the growth of weeds and cover plants, increasing their biomass and, possibly, their ability to compete for water and nutrients. As a result, the development of both shoots and roots of tree seedlings was inhibited. Indeed, in the presence of highly productive exotic grasses, increased nutrient availability in savannas may result in competitive exclusion of broad-leaved species by exotic grasses (Riginos 2009; Cramer et al. 2012).

\section{Considerations for Expanding Direct Seeding to Neotropical Savannas}

This study shows that seedling emergence and survival rates are high for some species, supporting the use of direct seeding for Brazilian savanna restoration. However, this and other studies have shown that only a limited number of species have high rates of establishment, and most species fail to emerge or have low early survival rates (Engel \& Parrotta 2001; Doust et al. 2006; Campos-Filho et al. 2014). To overcome the bottlenecks of emergence and survival, seeding methods need to be improved by adjusting planting depth, maintaining seed viability, reducing the incidence of pathogens and herbivores, inhibiting weeds, and reducing the exposure to high temperatures in open areas to prevent seed desiccation. Techniques to break dormancy might be a good strategy to accelerate seed germination, but it also synchronizes germination with the first rains and increases the likelihood of mass death from dry spells or herbivore attacks.

Perhaps the strongest limitation of the direct seeding technique in Brazilian savannas is the slow growth rate of seedlings. 
In this study, the largest seedling was only $0.78 \mathrm{~m}$ tall after 2 years. The slow growth of tree seedlings in savanna ecosystems enables the establishment of invasive species, which compete aggressively with native trees (D'Antonio \& Vitousek 1992). The attempt to stimulate seedling growth with fertilization reduced the establishment and growth rates of some species by favoring crops and weeds. It is therefore necessary to implement long-term management practices, such as weeding invasive plants and preventing fires, while the native plants are small. The inclusion of native grasses, herbs, and shrubs to cover the ground before exotic plants colonize may also be worthwhile. Currently, the low growth rate of savanna trees is used to justify the use of tropical forest trees in restoration, forestry, and agroforestry projects, in detriment of cerrado species. However, forest species require fertilization and are more susceptible to fire, rendering the ecosystem as a whole less resistant to fire.

Although the degree of shading provided by the crop cover did not increase tree seedling establishment and growth, we recommend its use during the initial phases of the restoration. While trees grow, planted crops produce food and are a source of income, and may therefore potentiate the involvement of farmers and landowners in management activities. Weeding unwanted plants for agricultural species also benefits tree seedlings, improving their survival and growth (Somarriba et al. 2001; Vieira et al. 2009). Future studies should address crop species composition, spacing, and timing of seeding, with the goal of conciliating native species establishment with crop production.

\section{Acknowledgments}

We acknowledge the staff of Fazenda Sucupira (EMBRAPA Transferência de Tecnologia) for logistic support. D.M.T. Brandão, R. Niemeyer, G.M. Rezende, and C. Motta helped with fieldwork. Experimental design was benefited from Ernest Gotsch's thoughts, presented during his agroforestry course. B. Baker provided English editing. D.R. Oliveira, G.P.E. da Rocha, and R.R.P. Silva had CNPq grants (DTI-C). Funding was provided by CNPq (Edital 26/2010, Proc. 561847/2010-0).

\section{LITERATURE CITED}

Balandier P, Frochot H, Sourisseau A (2009) Improvement of direct tree seeding with cover cropsas in afforestation: microclimate and resource availability induced by vegetation composition. Forest Ecology and Management 257:1716-1724

Barbosa AR, Yamamoto K, Valio IFM (1999) Effect of light and temperature on germination and early growth of Vochysia tucanorum Mart., Vochysiaceae, in cerrado and forest soil under different radiation levels. Revista Brasileira de Botânica 22:275-280

Belsky AJ, Mwonga SM, Amundson RG, Duxbury JM, Ali AR (1993) Comparative effects of isolated trees on their undercanopy environments in high-rainfall and low-rainfall savannas. Journal of Applied Ecology 30: $143-155$

Campos-Filho EM, da Costa JNMN, de Sousa OL, Junqueira RGP (2014) Mechanized direct-seeding of native forests in Xingu, Central Brazil. Journal of Sustainable Forestry 32:702-727

Clark CJ, Poulsen JR, Levey DJ (2013) Roles of seed and establishment limitation in determining patterns of afrotropical tree recruitment. Plos One 8:e63330
Cole RJ, Holl KD, Keene CL, Zahawi RA (2011) Direct seeding of late-successional trees to restore tropical montane forest. Forest Ecology and Management 261:1590-1597

Cramer MD, Wakeling JL, Bond WJ (2012) Belowground competitive suppression of seedling growth by grass in an African savanna. Plant Ecology 213:1655-1666

D’Antonio CM, Vitousek PM (1992) Biological invasions by exotic grasses, the grass fire cycle, and global change. Annual Review of Ecology and Systematics 23:63-87

de Souza ERB, Carneiro IF, Naves RV, Borges JD, Leandro WM, Chaves LJ (2001) Emergência e crescimento de cagaita (Eugenia dysenterica DC.) em função do tipo e do volume de substratos. Pesquisa Agropecuária Tropical (Agricultural Research in the Tropics) 31:89-95

Dostalek J, Weber M, Matula S, Frantik T (2007) Forest stand restoration in the agricultural landscape: the effect of different methods of planting establishment. Ecological Engineering 29:77-86

Doust SJ, Erskine PD, Lamb D (2006) Direct seeding to restore rainforest species: microsite effects on the early establishment and growth of rainforest tree seedlings on degraded land in the wet tropics of Australia. Forest Ecology and Management 234:333-343

Doust SJ, Erskine PD, Lamb D (2008) Restoring rainforest species by direct seeding: tree seedling establishment and growth performance on degraded land in the wet tropics of Australia. Forest Ecology and Management 256:1178-1188

Durigan G, Guerin N, da Costa JNMN (2013) Ecological restoration of Xingu Basin headwaters: motivations, engagement, challenges and perspectives. Philosophical Transactions of the Royal Society, B: Biological Sciences 368:20120165

Engel VL, Parrotta JA (2001) An evaluation of direct seeding for reforestation of degraded lands in central Sao Paulo state, Brazil. Forest Ecology and Management 152:169-181

Felfili JM, Hilgbert LF, Franco AC, Silva JCS, Resende AB, Nogueira MVP (1999) Comportamento de plântulas de Sclerolobium paniculatum Vog. var. rubiginosum (Tul.) Benth. sob diferentes níveis de sombreamento, em viveiro. Revista Brasileira de Botânica 22:297-301

Gómez-Aparicio L, Zamora R, Gomez JM, Hodar JA, Castro J, Baraza E (2004) Applying plant facilitation to forest restoration: a meta-analysis of the use of shrubs as nurse plants. Ecological Applications 14:1128-1138

Higgins SI, Bond WJ, Trollope WSW (2000) Fire, resprouting and variability: a recipe for grass-tree coexistence in savanna. Journal of Ecology 88:213-229

Hoffmann WA (1998) Post-burn reproduction of woody plants in a neotropical savanna: the relative importance of sexual and vegetative reproduction. Journal of Applied Ecology 35:422-433

Hoffmann WA, Franco AC (2003) Comparative growth analysis of tropical forest and savanna woody plants using phylogenetically independent contrasts. Journal of Ecology 91:475-484

Hoffmann WA, Solbrig OT (2003) The role of topkill in the differential response of savanna woody species to fire. Forest Ecology and Management 180:273-286

Holmgren M, Scheffer M, Huston MA (1997) The interplay of facilitation and competition in plant communities. Ecology 78:1966-1975

INMET (2014) Instituto Nacional de Meteorologia. http://www.inmet.gov.br/ portal/ (accessed 13 May 2014)

Lacerda KAP, Silva MMS, Carneiro MAC, Reis EF, Saggin Júnior OJ (2011) Fungos micorrízicos arbusculares e adubação fosfatada no crescimento inicial de seis espécies arbóreas do cerrado. Cerne 17:377-386

Lapola DM, Martinelli LA, Peres CA, Ometto JPHB, Ferreira ME, Nobre CA, et al. (2014) Pervasive transition of the Brazilian land-use system. Nature Climate Change 4:27-35

Martinotto F, Martinotto C, Coelho MDFB, Azevedo RAB, Albuquerque MCDF (2012) Survival and initial growth of tree species native to the Cerrado intercropped with cassava. Pesquisa Agropecuária Brasileira 47:22-29

Moreira AG (2000) Effects of fire protection on savanna structure in Central Brazil. Journal of Biogeography 27:1021-1029 
Muehlethaler U, Kamm U (2009) Innovative direct seeding method in the forest. Agrarforschung 16:384-389

Padilla FM, Pugnaire FI (2006) The role of nurse plants in the restoration of degraded environments. Frontiers in Ecology and the Environment 4:196-202

Riginos C (2009) Grass competition suppresses savanna tree growth across multiple demographic stages. Ecology 90:335-340

Salazar A, Goldstein G, Franco AC, Miralles-Wilhelm F (2011) Timing of seed dispersal and dormancy, rather than persistent soil seed-banks, control seedling recruitment of woody plants in Neotropical savannas. Seed Science Research 21:103-116

Salazar A, Goldstein G, Franco AC, Miralles-Wilhelm F (2012a) Differential seedling establishment of woody plants along a tree density gradient in Neotropical savannas. Journal of Ecology 100:1411-1421

Salazar A, Goldstein G, Franco AC, Miralles-Wilhelm F (2012b) Seed limitation of woody plants in neotropical savannas. Plant Ecology 213:273-287

Salomão AN, Davide AC, Firetti F, Sosa-Silva JC, Caldas LS, Wetzel MMVS, Torres RAA, Gonzáles S (2003) Germinação de sementes e produção de mudas de plantas do Cerrado. Rede de Sementes do Cerrado, Brasília, Brazil

Sano EE, Rosa R, Brito JLS, Ferreira LG (2008) Mapeamento semidetalhado do uso da terra do Bioma Cerrado. Pesquisa Agropecuária Brasileira 43:153-156

Sassaki RM, Felippe GM (1998) Response of Dalbergia miscolobium Benth. seedlings, a cerrado tree species, to mineral nutrient supply. Brazilian Journal of Botany 21:65-72

Silva LDCR, Corrêa RS (2008) Sobrevivência e crescimento de seis espécies arbóreas submetidas a quatro tratamentos em área minerada no cerrado. Revista Árvore 32:731-740

Somarriba E, Valdivieso R, Vasquez W, Galloway G (2001) Survival, growth, timber productivity and site index of Cordia alliodora in forestry and agroforestry systems. Agroforestry Systems 51:111-118

Truax B, Gagnon D (1993) Effects of straw and black plastic mulching on the initial growth and nutrition of butternut, white ash and bur oak. Forest Ecology and Management 57:17-27

Viani RAG, Rodrigues RR, Dawson TE, Oliveira RS (2011) Savanna soil fertility limits growth but not survival of tropical forest tree seedlings. Plant and Soil 349:341-353

Coordinating Editor: Giselda Durigan
Vieira DLM, Holl KD, Peneireiro FM (2009) Agro-Successional Restoration as a Strategy to Facilitate Tropical Forest Recovery. Restoration Ecology $17: 451-459$

Wallin L, Svensson BM, Lonn M (2009) Artificial dispersal as a restoration tool in meadows: sowing or planting? Restoration Ecology 17:270-279

Walter BMT, Sampaio AB (1998) A vegetação da Fazenda Sucupira. Embrapa Recursos Genéticos e Biotecnologia, Brasília, Brazil

\section{Supporting Information}

The following information may be found in the online version of this article:

Figure S1. Diagram depicting the direct seeding experiment. Treatments are represented by NC (no crops), Crops (crops), GM (green manure), U (unfertilized), NPK, PL (poultry litter). The nine treatment combinations were replicated in four blocks (nine 30-m-long rows per block). Letters A to L represent the 12 species sown per meter in each row.

Figure S2. Mean seedling height and diameter of six cerrado tree species 398 days after seeds were sown in rows with different levels of fertilization (U, unfertilized; NPK; or PL, poultry litter) and plant cover (NC, no cover; crops; or GM, green manure). Error bars show standard error. For each species, significant differences are shown at the top of the plot, using a greater than symbol to indicate the relatively best treatments based on factorial ANOVAs followed by Tukey tests (Table S2). Values were back-transformed from log.

Figure S3. Mean seedling height of six cerrado tree species 780 days after seeds were sown in rows with different levels of fertilization (U, unfertilized; NPK; or PL, poultry litter) and plant cover (NC, no cover; crops; or GM, green manure). Error bars show standard error. For each species, significant differences are shown at the top of the plot, using a greater than symbol to indicate the relatively best treatments based on factorial ANOVAs followed by Tukey tests (Table S2). Values were back-transformed from log. Table S1. Results of factorial ANOVAs for seedling emergence establishment (no. surviving seedlings at 780 days/no. seeds sown) and total biomass (log-transformed) at 135 days for six cerrado tree species, including the effects of fertilization (unfertilized, NPK, or poultry litter) and plant cover (no cover, crops, or green manure). Significant $p$ values are in bold, sample sizes within brackets.

Table S2. Results of factorial ANOVAs for seedling height $(\mathrm{cm})$ and diameter $(\mathrm{mm})$ of six cerrado tree species 398 and 780 days after sowing, including the effects of fertilization (unfertilized, NPK, or poultry litter) and plant cover (no cover, crops, or green manure). Significant $p$ values are in bold, sample sizes within brackets.

Received: 14 August, 2014; First decision: 17 September, 2014; Revised: 11 March, 2015; Accepted: 12 March, 2015; First published online: 28 April, 2015 